\title{
Schistosomiasis mansoni and severe gastrointestinal cytomegalovirus disease in a patient with acquired immunodeficiency syndrome
}

\section{Esquistossomose mansoni e doença gastrointestinal grave pelo citomegalovírus em paciente com a síndrome da imunodeficiência adquirida}

\author{
Renata Eliane de Ávila1, Thaís Sanai Batista1, Marcelo Antônio Pascoal Xavier², \\ Ana Margarida Miguel Ferreira Nogueira ${ }^{2}$ and José Roberto Lambertucci ${ }^{1}$
}

\begin{abstract}
The behavior of the Schistosoma mansoni infection in patients with AIDS has not been explored. The case of a young woman with schistosomiasis mansoni, AIDS, and cytomegalovirus disease is reported. The authors suggest that the helminth was not a bystander in this case, or rather, by interfering with the host's immune response, it set the stage for the development and/or aggravation of the viral infection.
\end{abstract}

Key-words: Schistosomiasis. Schistosoma mansoni. AIDS. Cytomegalovirus. Immunodeficiency. Lymphocytes.

\section{RESUMO}

O comportamento da infecção pelo Schistosoma mansoni não foi explorado em pacientes com AIDS. Relatamos aqui o caso de uma paciente com esquistossomose mansoni, AIDS, e doença pelo citomegalovírus. Os autores sugerem que o helminto não foi apenas um espectador neste caso, mas, que, ao interferir na resposta imune do hospedeiro, promoveu o surgimento e/ou agravamento da infecção causada pelo citomegalovírus.

Palavras-chaves: Esquistossomose. Schistosoma mansoni. AIDS. Citomegalovírus. Imunodeficiência. Linfócitos.

It has been estimated that 4-6 million people are infected by Schistosoma mansoni in Brazil, and 600 thousand by the human immunodeficiency virus (HIV-1). Reports on the association of schistosomiasis and AIDS are scarce but they have begun to appear in the literature. In Africa, a group of investigators found evidence that schistosomiasis may have an effect on plasma HIV concentration in coinfected individuals and also on the density of HIV-1 coreceptors CCR5 and CXCR4 on the surfaces of CD $4+$ cells $^{17}$.

In Brazil, patients who died with AIDS and were found at autopsy to also be coinfected with $S$. mansoni, unveiled some interesting data ${ }^{15}$ : 1) small and incomplete granulomas were observed around the eggs deposited in the tissues; and 2) a miliary distribution of eggs occurred in many organs (liver, spleen, lungs, intestine, pancreas and testes). The inferences derived from these cases and based on previous experimental work ${ }^{3} 58$, were of two kinds: a) without well formed granulomas the eggs do not reach the gut lumen and diagnosis of schistosomiasis based on stool examination is not possible; and b) without good immunity, the worms are not confined to the mesenteric vessels, migrate to unusual places in the body and lay their eggs in different organs ${ }^{9}$.

Cytomegalovirus (CMV) is the most common opportunistic viral infection in patients with AIDS. Autopsy studies have shown that up to $81 \%$ of HIV-infected patients presented clinical and pathologic evidence of CMV disease at the time of their death. Gastrointestinal involvement in CMV infection accounts for $5-10 \%$ of HIV-infected patients and occurs when the CD $4+\mathrm{T}$ cell count falls below $100 / \mathrm{mm}^{3}$. This disease is an erosive or ulcerative process that can occur at any location in the gastrointestinal tract, from the mouth to the rectum ${ }^{16}$.

\footnotetext{
1. Serviço de Doenças Infecciosas e Parasitárias do Departamento de Clínica Médica da Faculdade de Medicina da Universidade Federal de Minas Gerais, Belo Horizonte, MG. 2. Departamento de Anatomia Patológica da Faculdade de Medicina da Universidade Federal de Minas Gerais, Belo Horizonte, MG. Address to: Prof. José Roberto Lambertucci. Dept ${ }^{\circ}$ de Clínica Médica/FM/UFMG. Av. Alfredo Balena 190, 30130-100 Belo Horizonte, MG, Brasil. e-mail: lamber@uai.com.br Recebido para publicação em 1/9/2005 Aceito em 12/7/2006
} 
Herein, the case of a patient with AIDS, severe gastrointestinal cytomegalovirus disease and who also proved to be coinfected with $S$. mansoni, after examination of part of the intestine removed during surgery, is reported.

\section{CASE REPORT}

A 32-year-old woman was admitted to hospital reporting a $15 \mathrm{~kg}$-weight loss over the previous 3 months. She also complained of malaise, diarrhea, abdominal pain and odynophagia. Clinical examination upon admission revealed an emaciated young woman with severe oral candidiasis. Blood tests disclosed anemia and lymphocytopenia ( $\mathrm{T} \mathrm{CD} 4+=61 \mathrm{cels} / \mathrm{mm}^{3}$ ). ELISA for HIV proved positive, with a plasma viral load of $24,000 / \mathrm{ml}$. Upper endoscopy confirmed the diagnosis of esophageal candidiasis and also revealed multiple ulcers on the esophagus. Under light microscopy, biopsies of the ulcers showed cells with inclusion bodies suggestive of CMV esophagitis. Ultrasound of the

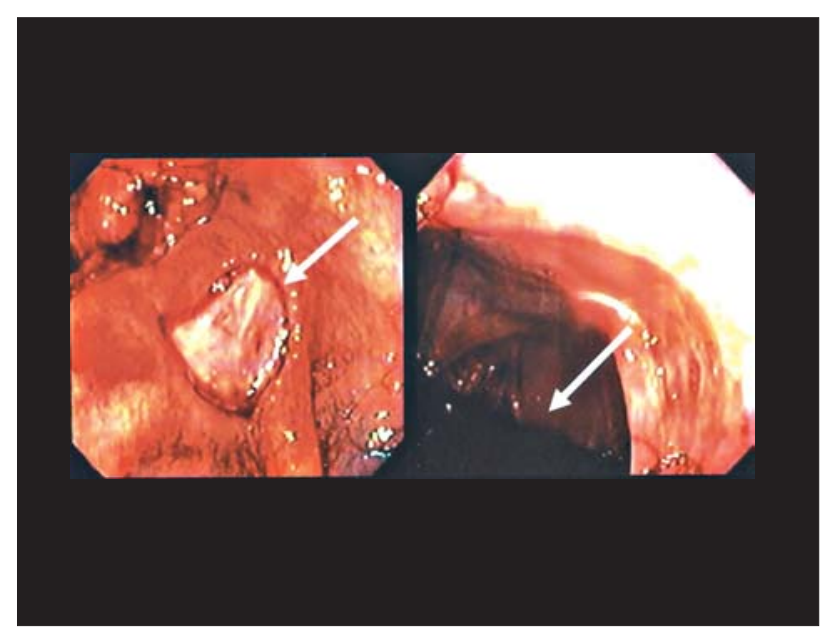

Figure 1 - Colonoscopy showing a bleeding ulcer on the left (arrow) and blood in the intestinal lumen on the right (arrow).

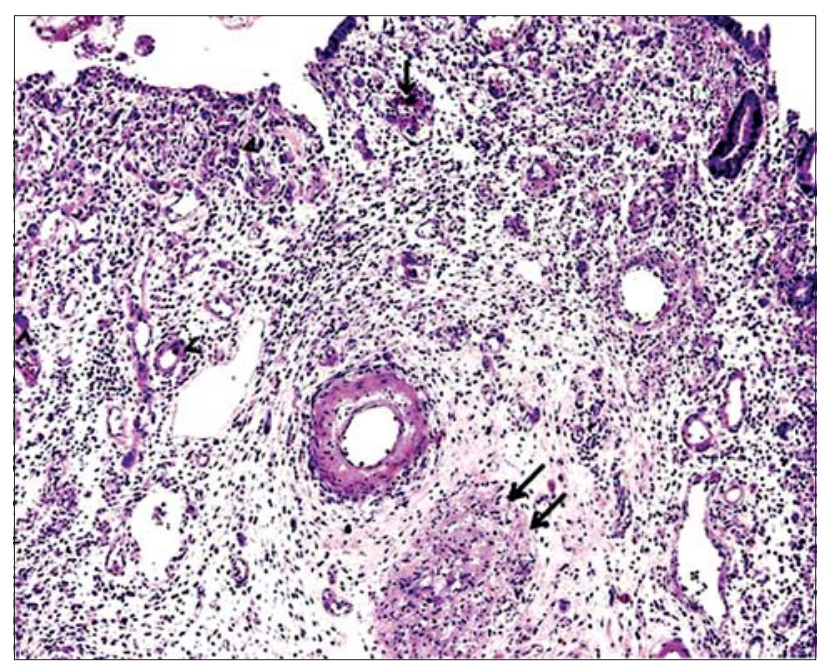

Figure 3 - Base of CMV ulcers showing mild inflammation, granulation tissue, vasculitis and thrombus formation with vascular occlusion (arrows). Cytomegalic inclusions occurred in endothelial cells of arterioles, venules and capillaries (arrow-heads). abdomen was normal, except for a thickening of the wall of the distal ileum. Stool examinations were negative for eggs of helminthes or other parasites. Ten days after admission she developed sudden and severe intestinal hemorrhage followed by refractory shock. A colonoscopy performed during the episode showed numerous shallow bleeding ulcerations throughout the large bowel and distal ileum (Figure 1); the lesions were more intense in the right colon, cecum and distal ileum. The patient was operated on and the right colon and distal ileum were excised (Figure 2). Histopathology revealed several ulcers extending deep into the bowel wall. Endothelial cells of arterioles, venules and capillaries showed inclusion bodies suggestive of CMV infection (Figures 3 e 4). A large number of viable eggs of $S$. mansoni were described in the lamina propria and, characteristically, they were not surrounded by granulomas or any other inflammatory cells (Figure 4). After surgery the patient was transferred to an intensive care unit (ICU) and improved rapidly. Treatment for schistosomiasis with praziquantel $(50 \mathrm{mg} / \mathrm{kg}$, body weight) was begun. She was placed on total parenteral nutrition, received intravenous

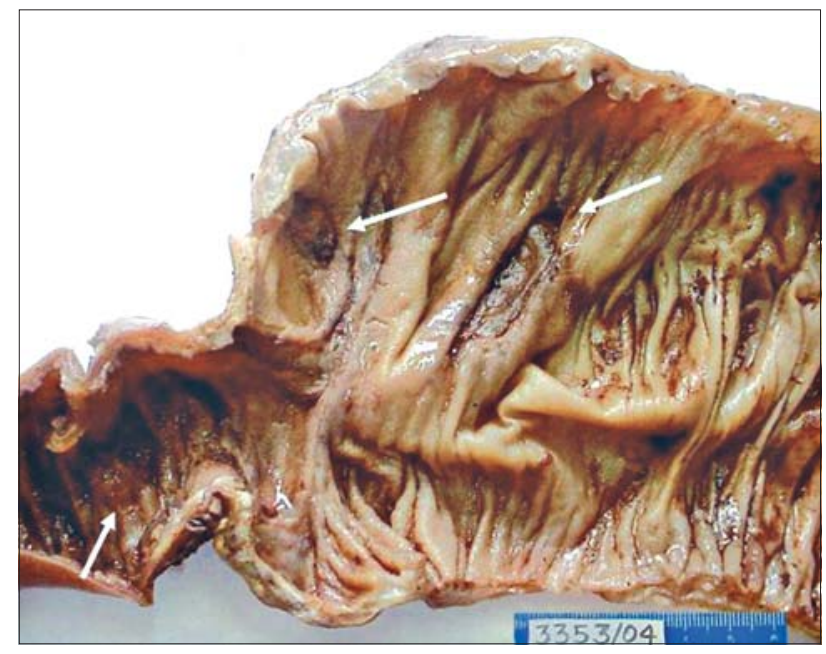

Figure 2 - Macroscopic appearance of the colon and distal ileum showing several sharply acute ulcers (arrows) extending deep into the bowel wall.

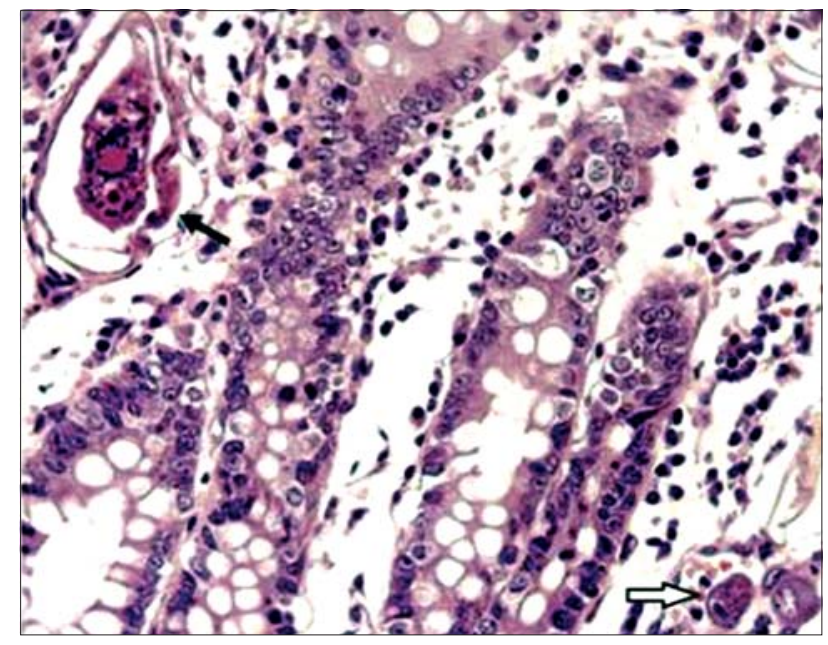

Figure 4 - Schistosoma mansoni viable egg in lamina propria without any inflammatory reaction on the upper left hand corner (black arrow). Enlarged and prominent endothelial CMV-infected cell (cytomegalic cell) with granular basophilic cytoplasm and containing one esinophilic intranuclear inclusion surrounded by a halo (white arrow). 
ganciclovir for cytomegalovirus infection and a highly active antiretroviral regimen for the treatment of AIDS. She was discharged from the ICU 5 days after admission and stayed in the infirmary for a further two months. One year later she was reexamined at the outpatient clinic and was feeling well. Her T CD $4+$ cell count was $224 / \mathrm{mm}^{3}$ and the HIV viral load was not measurable.

\section{DISCUSSION}

No inflammatory response around viable eggs of $S$. mansoni was observed in the patient herein reported, who presented with a severe disruption of the immune system. This is consistent with experimental work carried out on murine schistosomiasis, which showed that mice immunosuppressed by drugs or thymectomy plus irradiation, did not form granulomas around $S$. mansoni eggs deposited in tissues ${ }^{2}{ }^{3}$. Granuloma formation is immune mediated and T CD 4 + lymphocytes, particularly of the Th2 subset, play a central role in the inflammatory response to eggs of the parasite ${ }^{2}{ }^{13}$. Parasitological stool examinations in this patient failed to reveal Schistosoma mansoni eggs. This was expected, because a fully formed granuloma is important in the extrusion of eggs from the intestinal mucosa into the stools.

Data from human studies support the hypothesis that people with helminth infections are more susceptible to HIV-1 infection and/or experience increased viral replication. Cells from individuals with schistosomiasis, intestinal helminthes, or filariasis are more susceptible to HIV-1 infection in vitro, than are cells from individuals without helminth infection. In addition, some authors have shown that HIV-1 replicates more readily in T helper 2 cell (Th2) environments, such as those caused by schistosome infection ${ }^{13}$. Similarly, the deviation of the immune system to a Th2 response caused by the worm would facilitate the state of chronic staphylococci carrier in the nasal mucosa and the eventual formation of pyogenic abscesses of the liver and muscles ${ }^{711} 16$.

The patient developed a severe gastrointestinal cytomegalovirus disease, which was the reason for her admission to hospital and that almost caused her death. To control viral infections, the host depends mostly on mounting a solid Th1 immune response. Given the above information, it is possible to speculate that schistosomiasis may have played a contributing role in the severe evolution of the cytomegalovirus infection in this patient.

It also seems appropriate to comment here on the Salmonella-S. mansoni association, described mostly in Brazil and Africa. Lambertucci and Neves (1993) reported the case of a patient with this association who died and whose coinfection with tuberculosis in its miliary form was found during autopsy ${ }^{9}$. At this point, $S$. mansoni eggs were described in many organs, with incomplete granuloma formation around them. This is an example of the fact that different diseases evolving with severe immunosuppression will eventually present a similar pathological picture. On another occasion, two other patients with AIDS were also coinfected with Salmonella and $S$. mansoni. Treatment of schistosomiasis alone with oxamniquine cured the Salmonella bacteremia, produced a rapid improvement in the clinical picture and increased the T CD4 + cell counts to a level where treatment with highly active antiretroviral chemotherapy was no longer required $^{10}$.

Oxamniquine and praziquantel have been used in Brazil for a long time now and are equally successful in the treatment of schistosomiasis mansoni. However, the efficacy of both drugs has been shown to be immunodependent ${ }^{58}$. Thus, a natural anxiety and preoccupation regarding the efficacy of both drugs in the treatment of schistosomiasis in patients with AIDS occurred. In our patient, schistosomiasis was diagnosed only by histology. After treatment with praziquantel, parasitological stool examinations have been repeated at the outpatient clinic up to one year after release from the hospital, and, so far, they remain negative for $S$. mansoni eggs.

In short, the case of a patient with AIDS, severe gastrointestinal cytomegalovirus infection and intestinal schistosomiasis mansoni is reported. The authors suggest that the worm was not a bystander in this case, or rather, by interfering in the host's immune response, it set the stage for the development and/or aggravation of the viral infection.

\section{REFERENCES}

1. Beaugerie L, Cywiner-Golenzer C, Monfort L, Girard PM, Carbonnel F, Ngô Y, Cosnes J, Rozenbaum W, Nicolas JC, Châtelet FP, Gendre JP. Definition and diagnosis of cytomegalovirus colitis in patients infected by the human immunodeficiency virus. Journal of Acquired Immune Deficiency Syndromes \& Human Retrovirology 14: 423-429, 1997.

2. Buchanam RD, Fine DP, Colley DG. Schistosoma mansoni: infection in mice depleted of thymus-dependent lymphocytes II. Pathology: altered pathogenesis. American Journal of Pathology 71: 208-218, 1973.

3. Doenhoff MJ, Hassounah OA, Murare H, Bain J, Lucas SB. The schistosome egg granuloma: immunopathology in the cause of host protection or parasite survival? Transactions of the Royal Society of Tropical Medicine and Hygiene 80: 503-514, 1986.

4. Doenhoff MJ, Modha J, Lambertucci JR. Anti-schistosome chemotherapy enhanced by antibodies specific for a parasite esterase. Immunology 65: 507-510, 1988.

5. Doenhoff, MJ, Modha J, Lambertucci JR, MacLaren DJ. The immune dependence of chemotherapy. Parasitology Today 7: 16-18, 1991.

6. Goodgame RW. Gastrointestinal cytomegalovirus disease. Annals of Internal Medicine 119: 924-935, 1993.

7. Lambertucci JR. Hyperimmunoglobulinemia E, parasitic diseases and staphylococcal infection. Revista da Sociedade Brasileira de Medicina Tropical 23: 239-240, 1996.

8. Lambertucci JR, Modha J, Doenhoff MJ. Schistosoma mansoni: the therapeutic efficacy of oxamniquine is enhanced by immune serum. Transactions of the Royal Society of Tropical Medicine and Hygiene 83: 362-363, 1989.

9. Lambertucci JR, Neves J. Associação Salmonella-SchistosomaMycobacterium: relato de um caso. Arquivos Brasileiros de Medicina 67: 53-54, 1993.

10. Lambertucci JR, Raves AAM, Gerspacher-Lara R. Salmonella-S. manson association in patients with the acquired immunodeficiency syndrome. Revista do Instituto de Medicina Tropical de São Paulo 40: 233-235, 1998.

11. Lambertucci JR, Rayes AA, Nunes F, Landazuri-Palacios JE, Nobre V. Fever of undetermined origin in patients with the acquired immunodeficiency syndrome in Brazil: report on 55 cases. Revista do Instituto de Medicina Tropical de São Paulo 41: 27-32, 1999. 
12. Lambertucci JR, Rayes AA, Serufo JC, Nobre V. Pyogenic abscesses and parasitic diseases. Revista do Instituto de Medicina Tropical de São Paulo 43: 67-74, 2001

13. Maggi E, Mazzetti M, Ravina A. Ability of HIV to promote a Th1 to Th0 shift and to replicate preferentially in Th2 and Th0 cells. Science 265: 244-248, 1994.

14. Modha J, Lambertucci JR, Doenhoff MJ, McLaren DJ. Immune dependence of schistosomicidal chemotherapy: an ultrastructural study of Schistosoma mansoni adult worms exposed to praziquantel and immune serum in vivo. Parasite Immunology 12: 321-334, 1990.
15. Nobre V, Braga E, Raves A, Serufo JC, Godoy P, Nunes N, Antunes CM, Lambertucci JR. Opportunistic infections in patients with AIDS admitted to an university hospital of the Southeast of Brazil. Revista do Instituto de Medicina Tropical de São Paulo 45: 69-74, 2003.

16. Rayes AA, Nobre V, Teixeira DM, Serufo JC, Brasileiro Filho G, Antunes CM, Lambertucci JR. Tropical pyomyositis and human toxocariasis: a clinical and experimental study. American Journal of Medicine 109: 422-425, 2000.

17. Secor WE, Karanja DMS, Colley DG. Interaction between schistosomiasis and the human immunodeficiency virus (HIV-1) in Western Kenya. Memórias do Instituto Osvaldo Cruz 99 (supl 1): 93-95, 2004. 